\title{
Penerapan Model Pembelajaran Kooperatif Tipe Think-Pair-Share Untuk Meningkatkan Pemahaman Siswa Tentang Shalat Sunnah
}

\author{
Wahyu Hidayat ${ }^{1 *}$, Muzakkir ${ }^{2}$, Hamsiah ${ }^{3}$, Irnawati ${ }^{4}$ \\ Institut Agama Islam Negeri (IAIN) Parepare*1,2,4 ${ }^{*}$ MAN 1 Parepare*3 \\ ${ }^{*}$ email: wahyuhidayat@iainpare.ac.id,
}

Abstract
Cooperative learning model Think Pair Share is a process of
learning activities that includes providing material, group
division, giving questions, giving questions and delivering the
results of group discussions conducted by students.
Cooperative Think Pair Share type centers on students so that
students play an active role and are directly involved in the
learning process. This research process was carried out
because of the learning process which was still classified as
classic and less effective. In addition, the role of students is
still not maximized then the learning process which takes
place in the morning and afternoon today makes students
bored and bored with the subject matter. This is the lack of
understanding of students about prayer, especially Sunnah
prayer and lack of interest, enthusiasm and learning outcomes
of students in the learning process in Islamic Education
subjects. This study aims to improve students' understanding
of Sunnah prayer in Islamic Education subjects by applying
the Think Pair Share Type Cooperative learning model in
class VIII.3 SMP Negeri 2 Mattirobulu, Pinrang. The variable
that becomes the target of change in this study is the result of
increasing student understanding, while the action variable
used in this study is the Think Pair Share Type Cooperative
learning model. This type of research is a classroom action
research conducted in 2 cycles, each cycle consisting of four
stages, namely planning, acting, observing, and reflecting.
The data collection techniques used was observation,
interviews, tests and documentation. The data analysis
techniques used were quantitative and qualitative descriptive
analysis techniques. The results showed that the learning
outcomes of students from cycle I to cycle II had increased.
Thus, it can be concluded that the application of the Think
Pair Share Type Cooperative learning model can improve the
results of students' understanding of Sunnah prayer at SMP
Negeri 2 Mattirobulu, Pinrang.
Keywords: Cooperative Think Pair Share, Understanding
Sunnayer.

Artikel Info

Received:

03 February 2021

Revised:

21 April 2021

Accepted:

01 June 2021

Published:

10 June 2021 


\section{Abstrak}

Model pembelajaran kooperatif tipe Think Pair Share merupakan suatu proses kegiatan pembelajaran yang meliputi pemberian materi, pembagian kelompok, pemberiansoal, pemberian pertanyaan-pertanyaan dan penyampaian hasil diskusi kelompok yang dilakukan oleh siswa. Kooperatif Tipe Think Pair Share berpusat pada peserta didik sehingga peserta didik berperan aktif dan terlibat langsung dalam proses pembelajaran.

Proses penelitian ini dilakukan karena adanya proses pembelajaran yang masih tergolong klasik dan kurang efektif. Selain itu, peran peserta didik masih kurang dimaksimalkan kemudian proses pembelajaran yang berlangsung pada saat pagi dan siang hari ini membuat peserta didik jenuh dan bosan dengan materi pelajaran. Hal tersebut kurangnya pemahaman siswa tentang shalat terutamanya shalat sunnah dan kurangnya minat, semangat serta hasil belajar peserta didik dalam proses pembelajaran pada mata pelajaran Pendidikan Agama Islam (PAI). Penelitian ini bertujuan untuk meningkatkan Pemahaman siswa tentang shalat sunnah pada siswa mata pelajaran PAI dengan menerapkan model pembelajaran kooperatif tipe Think Pair Share dikelas VIII.3 SMP Negeri 2 Mattirobulu kabupaten Pinrang. Variabel yang menjadi sasaran perubahan dalam penelitian ini adalah hasil peningkatan pemahaman siswa, sedangkan variable tindakan yang digunakan dalam penelitian ini adalah model pembelajaran kooperatif tipe Think Pair Share. Jenis penelitian ini adalah penelitian tindakan kelas yang dilaksanakan dalam 2 siklus, setiap siklus terdiri dari empat tahapanya itu perencanaan, tindakan, pengamatan, dan refleksi. Adapun teknik pengumpulan data yang digunakan adalah pengamatan, wawancara, tes dan dokumentasi. Teknik analisis data yang digunakan adalah teknik analisis deskriptif kuantitatif dan secara kualitatif. Hasil penelitian menunjukkan bahwa hasil belajar peserta didik dari siklus I, hingga siklus II mengalami peningkatan. Dengan demikian, dapat disimpulkan bahwa penerapan model pembelajaran kooperatif tipe Think Pair Share dapat meningkatkan hasil pemahaman siswa tentang shalat sunnah di SMP Negeri 2 Mattirobulu Kabupaten Pinrang.

\section{Kata Kunci : Kooperatif Tipe Think Pair Share,} Pemahaman Shalat Sunnah. 
Vol. 13, No. 1 (June 2021)

\section{A. Pendahuluan}

Pembelajaran adalah upaya membelajarkan siswa untuk belajar. Kegiatan pembelajaran akan melibatkan siswa mempelajari sesuatu dengan cara efektif dan efisien (Yatim Riyanto, 2009). Sedangkan menurut Gagne yang yang dikutip oleh Eveline Siregal, pembelajaran dimaksudkan untuk menghasilkan belajar, situasi eksternal harus dirancang sedemikian rupa untuk mengaktifkan, mendukung, dan mempertahankan proses internal yang terdapat dalam setiap peristiwa belajar (Eveline Siregar \& Hartini Nara, 2011).

Berdasarkan temu awal, hasil belajar Pendidikan Agama Islam (PAI) kelas VIII di Sekolah Menengah Pertama(SMP) Negeri 2 Mattirobulu masih rendah. Hal ini ditunjukkan dari rata-rata nilai PAI yang masih dibawah nilai ketentuan minimal 65 . Berkaitan dengan pendapat tersebut, pembelajaran yang baik adalah pembelajaran yang menempatkan siswa bukan lagi sebagai objek dalam proses belajar mengajar melainkan sebagai subjek serta mitra dalam proses pembelajaran. Karena siswalah yang menempati posisi sentral dalam proses belajar mengajar. Ia dianggap sebagai subjek dalam proses belajar-mengajar karena secara kodrat tiap-tiap dari mereka telah memiliki potensi dan kemampuan tertentu. Untuk itu, siswa yang secara aktif mampu mengembangkan minat dan potensinya menurut tujuan, isi, dan cara yang disukainya serta dalam batas kemampuannya.

Oleh karena itu, disinilah peran guru sebagai fasilitator yang menyediakan kondisi agar siswa dapat belajar dengan baik, nyaman, serta menyenangkan. Jika guru berhasil menumbuhkan kebutuhan tersebut maka, siswa aktif mengalami, mencari, dan menemukan berbagai pengetahuan yang dibutuhkannya dengan bimbingan guru (Sardiman, 2012).

Salah satu alternatif metode pembelajaran yang dapat digunakan guru PAI untuk meningkatkan minat belajar serta mengaktifkan siswa dalam pembelajaran dikelas adalah pembelajaran Kooperatif tipe Think (berfikir), Pair (berpasangan), dan Share (bebagi). Kelebihan TPS adalah proses pembelajaran menjadi lebih menarik dan merangsang siswa untuk bekerjasama (Moningka \& Sahetapy, 2019; Pangestuti, 2017; Tembang, 2018; Yuliati, 2020). 
ISSN 1979-9950 (print) || ISSN 2598-0033 (online), http://jurnal.umsu.ac.id/index.php/intiqad

DOI: intiqad.v\%vi\%i.6763

Vol. 13, No. 1 (June 2021)

Pembelajaran kooperatif

merupakan model pembelajaran yang melibatkan partisipasi siswa dalam suatu kelompok kecil untuk saling berinteraksi. Bentuk pembelajaran dengan cara siswa belajar dan bekerja dalam kelompok-kelompok kecil secara kolaboratif, yang anggotanya terdiri dari 2,4 sampai dengan 6 orang yang mana setiap anggota bekerja sama dan membantu untuk memahami suatu bahan pelajaran. Jadi tujuan dari pembelajaran kooperatif ini adalah mengajarkan siswa untuk memiliki dua tanggung jawab, yaitu belajar untuk dirinya sendiri dan membantu sesame anggota untuk belajar (Abdul Majid, 2013; Putri et al., 2019; Sadipun, 2020)

Tipe think (berfikir) siswa diberi kesempatan untuk mencari jawaban tugas secara mandiri, sedangkan Pair (berpasangan) siswa bertukar fikiran dengan teman sebangku, dan Share (berbagi) siswa berdiskusi dengan pasangan lain (Listyarini \& Nafarin, 2020; Yatim Riyanto, 2009). Dengan demikian, pendekatan pembelajaran kooperatif tipe Think Pair Share, diharapkan dapat menghasilkan belajar siswa pada pelajaran pendidikan agama Islam. Penelitian ini bertujuan dalam meningkatan pemahaman siswa kelas VIII.3 SMP Negeri 2 Mattirobulu tentang shalat Sunnah dalam pembelajaran kooperatif tipe ThinkPair-Share (TPS).

\section{B. Metode Penelitian}

Jenis penelitian ini tergolong penelitian tindakan kelas (PTK) atau Classroom Action Research dimana penelitian ini memiliki peranan yang sangat penting dan strategi untuk meningkatkan mutu pembelajaran apabila di implementasikan dengan baik dan benar (Arikunto, 2017). Di implementasikan dengan benar, artinya sesuai dengan kaidah-kaidah PTK. Penelitian tindakan kelas di bagi dalam siklus masing-masing siklus terdiri dari perencanaan (planning), tindakan (action), observasi (observe), serta refleksi (reflect).

Subjek dalam penelitian tindakan ini adalah seluruh siswa kelas VIII.1 SMP Negeri 2 Mattirobulu Kabupaten Pinrang yang berjumlah 26 orang terdiri dari 13 laki-laki dan 13 perempuan. Pemilihan kelas VIII.3 berdasarkan nilai rata-rata yang paling rendah dibandingkan kelas lainnya. Teknik pengumpulan data yang digunakan 


\section{INTIQAD: JURNAL AGAMA DAN PENDIDIKAN ISLAM}

ISSN 1979-9950 (print) || ISSN 2598-0033 (online), http://jurnal.umsu.ac.id/index.php/intiqad

DOI: intiqad.v\%vi\%i.6763

Vol. 13, No. 1 (June 2021)

dalam penelitian ini adalah tes, observasi (check list), dan wawancara. Data yang bersifat kuantitatif seperti hasil belajar di analisis menggunakan statistik deskriptif yaitu rata-rata, simpangan baku, frekuensi, presentase. Data yang bersifat kualitatif dari hasil pengamatan dan wawancara melalui diantara secara kualitatif.

\section{Hasil dan Pembahasan}

\section{Pengamatan Awal}

Pengamatan awal ini dilakukan selama 2 kali pertemuan. Selama proses pembelajaran berlangsung, komunikasi hanya terjadi satu arah, yaitu peneliti lebih mendominasikan pembelajaran dan peneliti yang lebih aktif memberikan materi serta sedikitnya interaksi Tanya jawab peneliti kepada peserta didik. Peserta didik terlihat kurang antusias ketika proses pembelajaran sedang berlangsung kurang optimal. Hal ini terlihat dari peserta didik yang duduk dibelakang hanya terdiam dan tanpa aktivitas.Terkadang peserta didik yang duduk dibangku belakang juga ramai sendiri dengan teman sebangku dan antar meja. Aktivitas proses pembelajaran hanya terjadi pada peserta didik yang berada di bangku depan dan bertanya pada saat pembelajaran berlangsung.
Hasil observasi pra tindakan menunjukkan ada beberapa hal yang menjadi masalah dan harus diubah agar pembelajaran menjadi optimal, diantaranya yaitu:

Tabel 1. Aktivitas Belajar Peserta Didik

\begin{tabular}{|c|c|c|c|c|}
\hline \multirow{2}{*}{ No } & \multirow{2}{*}{$\begin{array}{c}\text { Aktifitas } \\
\text { Belajar } \\
\text { Peserta Didik }\end{array}$} & \multicolumn{2}{|c|}{ Pertemuan } & \multirow{2}{*}{$\begin{array}{l}\text { Rata-rata } \\
\text { Presentase }\end{array}$} \\
\hline & & $\underset{(\%)}{I}$ & $\underset{(\%)}{\text { II }}$ & \\
\hline 1 & $\begin{array}{l}\text { Peserta didik } \\
\text { masuk kelas } \\
\text { tepat waktu }\end{array}$ & 56 & 43 & 49,5 \\
\hline 2 & $\begin{array}{l}\text { Peserta didik } \\
\text { menjawab } \\
\text { salam dan } \\
\text { bersiap untuk } \\
\text { menerima } \\
\text { pelajaran } \\
\text { dengan berdoa } \\
\text { menurut agama } \\
\text { masing-masing }\end{array}$ & 60 & 56 & 58 \\
\hline 3 & $\begin{array}{l}\text { Peserta didik } \\
\text { yang hadir } \\
\text { mengucapkan } \\
\text { hadir dengan } \\
\text { santun ketika } \\
\text { namanya }\end{array}$ & 65 & 60 & 62,5 \\
\hline 4 & $\begin{array}{l}\text { Peserta didik } \\
\text { antusias untuk } \\
\text { mengikuti } \\
\text { pelajaran }\end{array}$ & 65 & 56 & 60,5 \\
\hline 5 & $\begin{array}{l}\text { Peserta didik } \\
\text { menjawab } \\
\text { pertanyaan dari } \\
\text { guru }\end{array}$ & 47 & 43 & 68,5 \\
\hline 6 & $\begin{array}{l}\text { Peserta didik } \\
\text { memperhatikan } \\
\text { penjelasan } \\
\text { guru }\end{array}$ & 43 & 65 & 75,5 \\
\hline 7 & $\begin{array}{l}\text { Peserta didik } \\
\text { aktif dalam } \\
\text { pembelajaran }\end{array}$ & 52 & 65 & 58,5 \\
\hline 8 & $\begin{array}{l}\text { Peserta didik } \\
\text { mencatat } \\
\text { penjelasan dari } \\
\text { guru }\end{array}$ & 43 & 56 & 49,5 \\
\hline
\end{tabular}


INTIQAD: JURNAL AGAMA DAN PENDIDIKAN ISLAM

ISSN 1979-9950 (print) || ISSN 2598-0033 (online), http://jurnal.umsu.ac.id/index.php/intiqad

DOI: intiqad.v\%vi\%i.6763

Vol. 13, No. 1 (June 2021)

\begin{tabular}{|c|l|c|c|c|}
\hline 9 & $\begin{array}{l}\text { Peserta didik } \\
\text { mendengarkan } \\
\text { arahan dari } \\
\text { guru }\end{array}$ & 60 & 60 & 60 \\
\hline 10 & $\begin{array}{l}\text { Peserta didik } \\
\text { terfokus pada } \\
\text { materi } \\
\text { pembelajaran }\end{array}$ & 56 & 47 & 51,5 \\
\hline 11 & $\begin{array}{l}\text { Peserta didik } \\
\text { menanggapi } \\
\text { perintah guru } \\
\text { untuk bertanya } \\
\text { hal-hal yang } \\
\text { belum } \\
\text { dipahami }\end{array}$ & 60 & 56 & 58 \\
\hline 12 & $\begin{array}{l}\text { Peserta didik } \\
\text { menyimpulkan } \\
\text { materi } \\
\text { pembelajaran }\end{array}$ & 69 & 43 & 56 \\
\hline 13 & $\begin{array}{l}\text { Peserta didik } \\
\text { membacakan } \\
\text { hasil diskusi } \\
\text { bersama } \\
\text { kelompoknya }\end{array}$ & 39 & 60 & 49,5 \\
\hline Peserta didik & 52 & 60 & 56 \\
\hline
\end{tabular}

Berdasarkan tabel 2 aktivitas belajar peserta didik yang didapat sebelum dilakukan tindakan diketahui bahwa rata-rata presentase aktivitas belajar peserta didik yaitu $58,10 \%$ dengan kriteria cukup yaitu antara (40\% $-60 \%)$.

\section{Pengamatan dan Tes Pada Siklus \\ I (Pertama)}

Pada pertemuan awal, peserta didik terlihat belum aktif dan kebingungan dalam proses pembelajaran. Hal ini dikarenakan peserta didik belum pernah/mengetahui model pembelajaran kooperatif tipe think pair share (TPS) yang diterapkan. Sebagian peserta didik sibuk berbicara dengan teman sebangku, tetapi setelah peserta didik didekati dan diperingatkan peserta didik tersebut kembali mengikuti pelajaran dengan sungguh-sungguh. Meskipun demikian secara umum perhatian, keaktifan dan kerjasama peserta didik sudah cukup baik dibandingkan dengan awal sebelum diterapkan model pembelajaran kooperatif tipe Think Pair Share (TPS). Selain itu, pengamatan juga dilakukan dengan menyiapkan lembar observasi yang telah dipersiapkan untuk mengetahui sejauh mana strategi pembelajaran kelompok dapat meningkatkan prestasi belajar peserta didik dalam memahami shalat Sunnah.

Kegiatan observasi/pengamatan ini dilakukan oleh peneliti sendiri. Adapun data peroleh aktivitas belajar peserta didik yang diperoleh pada siklus I (Pertama) adalah sebagai berikut:

Tabel 2. Data Aktivitas Belajar Peserta Didik Siklus I

\begin{tabular}{|c|c|c|c|c|}
\hline \multirow{2}{*}{ No } & \multirow{2}{*}{$\begin{array}{c}\text { Aktifitas } \\
\text { Belajar } \\
\text { Peserta } \\
\text { Didik }\end{array}$} & $\begin{array}{c}\text { I } \\
\mathbf{( \% )}\end{array}$ & $\begin{array}{c}\text { II } \\
(\mathbf{\%})\end{array}$ & $\begin{array}{c}\text { Pertemuan } \\
\text { Presenta } \\
\text { se }\end{array}$ \\
\hline & $\begin{array}{l}\text { Peserta didik } \\
\text { masuk kelas } \\
\text { tepat waktu }\end{array}$ & 100 & 100 & 100 \\
\hline
\end{tabular}


INTIQAD: JURNAL AGAMA DAN PENDIDIKAN ISLAM

ISSN 1979-9950 (print) || ISSN 2598-0033 (online), http://jurnal.umsu.ac.id/index.php/intiqad

DOI: intiqad.v\%vi\%i.6763

Vol. 13, No. 1 (June 2021)

\begin{tabular}{|c|c|c|c|c|}
\hline 2 & $\begin{array}{l}\text { Peserta didik } \\
\text { menjawab } \\
\text { salam dan } \\
\text { bersiap untuk } \\
\text { menerima } \\
\text { pelajaran } \\
\text { dengan } \\
\text { berdoa } \\
\text { menurut } \\
\text { agama } \\
\text { masing- } \\
\text { masing }\end{array}$ & 100 & 100 & 100 \\
\hline 3 & $\begin{array}{l}\text { Peserta didik } \\
\text { yang hadir } \\
\text { mengucapka } \\
\text { n hadir } \\
\text { dengan } \\
\text { santun ketika } \\
\text { namanya } \\
\text { disebut }\end{array}$ & 100 & 100 & 100 \\
\hline 4 & $\begin{array}{l}\text { Peserta didik } \\
\text { antusias } \\
\text { untuk } \\
\text { mengikuti } \\
\text { pelajaran }\end{array}$ & $\begin{array}{c}59,0 \\
9\end{array}$ & $\begin{array}{c}65,2 \\
1\end{array}$ & 62,17 \\
\hline 5 & $\begin{array}{l}\text { Peserta didik } \\
\text { menjawab } \\
\text { pertanyaan } \\
\text { dari guru }\end{array}$ & $\begin{array}{c}52,1 \\
7\end{array}$ & $\begin{array}{c}73,9 \\
1\end{array}$ & 63,04 \\
\hline 6 & $\begin{array}{l}\text { Peserta didik } \\
\text { memperhatik } \\
\text { an penjelasan } \\
\text { guru }\end{array}$ & $\begin{array}{c}59,0 \\
9\end{array}$ & $\begin{array}{c}78,2 \\
6\end{array}$ & 68,67 \\
\hline 7 & $\begin{array}{l}\text { Peserta didik } \\
\text { aktif dalam } \\
\text { pembelajaran }\end{array}$ & 63 & $\begin{array}{c}69,5 \\
6\end{array}$ & 66,28 \\
\hline 8 & $\begin{array}{l}\text { Peserta didik } \\
\text { mencatat } \\
\text { penjelasan } \\
\text { dari guru }\end{array}$ & 68 & $\begin{array}{c}52,1 \\
7\end{array}$ & 60 \\
\hline 9 & $\begin{array}{l}\text { Peserta didik } \\
\text { mendengarka } \\
\text { n arahan dari } \\
\text { guru }\end{array}$ & 63 & $\begin{array}{c}56,5 \\
2\end{array}$ & 59,76 \\
\hline 10 & $\begin{array}{l}\text { Peserta didik } \\
\text { terfokus pada } \\
\text { materi } \\
\text { pembelajaran }\end{array}$ & $\begin{array}{c}59,0 \\
9\end{array}$ & $\begin{array}{c}65,2 \\
1\end{array}$ & 62.15 \\
\hline
\end{tabular}

\begin{tabular}{|c|l|c|c|c|}
\hline 11 & $\begin{array}{l}\text { Peserta didik } \\
\text { menanggapi } \\
\text { perintah guru } \\
\text { untuk } \\
\text { bertanya hal- } \\
\text { hal yang } \\
\text { belum } \\
\text { dipahami }\end{array}$ & 63 & $\begin{array}{c}52,1 \\
7\end{array}$ & 57,58 \\
\hline 12 & $\begin{array}{l}\text { Peserta didik } \\
\text { menyimpulka } \\
\text { n materi } \\
\text { pembelajaran }\end{array}$ & 72 & 73,9 & 73 \\
\hline $\begin{array}{l}\text { Peserta didik } \\
\text { membacakan } \\
\text { hasil diskusi } \\
\text { bersama } \\
\text { kelompoknya }\end{array}$ & 54 & 56,5 & 2 & 55,26 \\
\hline 14 & $\begin{array}{l}\text { Peserta didik } \\
\text { mengucapka } \\
\text { n salam }\end{array}$ & 100 & 100 & 100 \\
\hline
\end{tabular}

Berdasarkan tabel 2, pengamatan aktivitas belajar siklus I (pertama) menunjukkan bahwa rata-rata skor perolehan aktivitas belajar peserta didik adalah $(73,42)$, angka ini berada pada kriteria baik yaitu antara 60\%-80\%, dengan demikian dapat dikatakan bahwa melalui model pembelajaran kooperatif tipe Think Pair Share (TPS) pada siklus I (pertama) peserta didik telah melakukan aktivitas belajar yang baik pada mata pelajaran pendidikan agama Islam.

Selain data aktivitas belajar peserta didik, peneliti juga melakukan tes untuk mengetahui hasil belajar peserta didik selama proses pembelajaran. Tes tersebut menunjukkan bahwa sebagian 
INTIQAD: JURNAL AGAMA DAN PENDIDIKAN ISLAM

ISSN 1979-9950 (print) || ISSN 2598-0033 (online), http://jurnal.umsu.ac.id/index.php/intiqad

DOI: intiqad.v\%vi\%i.6763

Vol. 13, No. 1 (June 2021)

peserta didik memiliki nilai prestasi belajar dengan kategori rendah dan sedang, hal tersebut dapat dikemukakan pada gambar 1 dibawah ini.

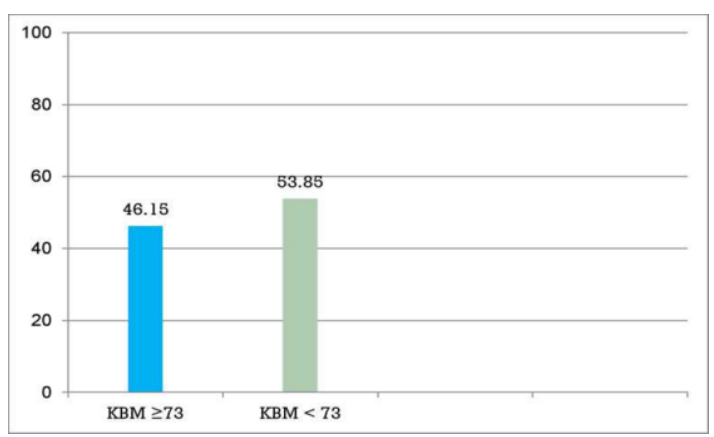

Gambar 1. Batang Prest Tes pada Siklus I (pertama)

Berdasakan pada gambar 1 mendeskripsikan bahwa peserta didik dengan kategori prestasi belajar masih banyak yang rendah

\section{Pengamatan dan Tes Pada Siklus II (Kedua)}

Selama pelaksanaan tahap pelaksanaan/tindakan siklus II (dua) berlangsung, juga dilakukan observasi terhadap peserta didik melalui format lembar observasi peserta didik yang sebelumnya telah dipersiapkan dengan tujuan untuk mengetahui sejauh mana model pembelajaran kooperatif tipe think pair share (TPS) dapat meningkatkan hasil belajar peserta didik yang dilakukan oleh peneliti sendiri. Adapun data perolehan aktivitas belajar peserta didik yang diperoleh pada siklus II (dua) adalah sebagai berikut:

Tabel 3. Data Aktivitas Belajar Peserta Didik Siklus II (Kedua)

\begin{tabular}{|c|c|c|c|c|}
\hline \multirow{2}{*}{ No } & \multirow{2}{*}{$\begin{array}{c}\text { Aktifitas } \\
\text { Belajar } \\
\text { Peserta Didik }\end{array}$} & \multicolumn{2}{|c|}{ Pertemuan } & \multirow{2}{*}{$\begin{array}{c}\text { Rata- } \\
\text { rata } \\
\text { Presentase }\end{array}$} \\
\hline & & $\begin{array}{c}\mathrm{I} \\
(\%)\end{array}$ & $\begin{array}{c}\text { II } \\
(\%)\end{array}$ & \\
\hline 1 & $\begin{array}{l}\text { Peserta didik } \\
\text { masuk kelas } \\
\text { tepat waktu }\end{array}$ & 100 & 100 & 100 \\
\hline 2 & $\begin{array}{l}\text { Peserta didik } \\
\text { menjawab } \\
\text { salam dan } \\
\text { bersiap untuk } \\
\text { menerima } \\
\text { pelajaran } \\
\text { dengan berdoa } \\
\text { menurut agama } \\
\text { masing-masing }\end{array}$ & 100 & 100 & 100 \\
\hline 3 & $\begin{array}{l}\text { Peserta didik } \\
\text { yang hadir } \\
\text { mengucapkan } \\
\text { hadir dengan } \\
\text { santun ketika } \\
\text { namanya } \\
\text { disebut }\end{array}$ & 100 & 100 & 100 \\
\hline 4 & $\begin{array}{l}\text { Peserta didik } \\
\text { antusias untuk } \\
\text { mengikuti } \\
\text { pelajaran }\end{array}$ & 65 & 91 & 78 \\
\hline 5 & $\begin{array}{l}\text { Peserta didik } \\
\text { menjawab } \\
\text { pertanyaan dari } \\
\text { guru }\end{array}$ & 69 & 78 & 73,5 \\
\hline 6 & $\begin{array}{l}\text { Peserta didik } \\
\text { memperhatikan } \\
\text { penjelasan } \\
\text { guru }\end{array}$ & 78 & 69 & 73,5 \\
\hline 7 & $\begin{array}{l}\text { Peserta didik } \\
\text { aktif dalam } \\
\text { pembelajaran }\end{array}$ & 78 & 78 & 78 \\
\hline 8 & $\begin{array}{l}\text { Peserta didik } \\
\text { mencatat } \\
\text { penjelasan dari } \\
\text { guru }\end{array}$ & 73 & 65 & 69 \\
\hline
\end{tabular}




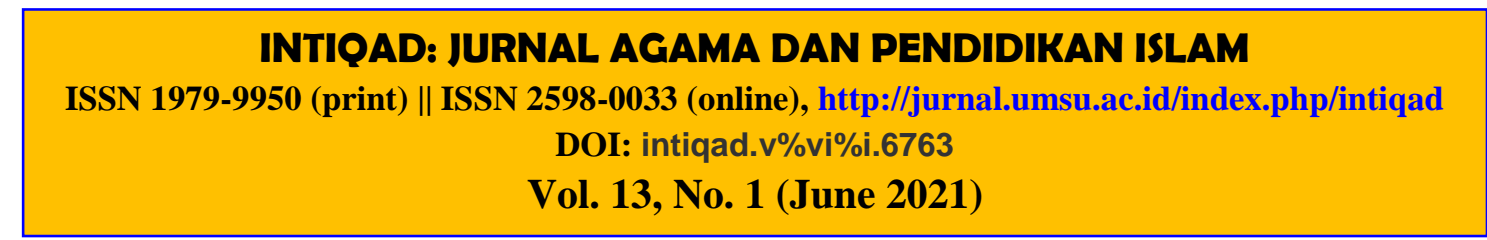

\begin{tabular}{|c|l|c|c|c|}
\hline 9 & $\begin{array}{l}\text { Peserta didik } \\
\text { mendengarkan } \\
\text { arahan dari } \\
\text { guru }\end{array}$ & 82 & 82 & 82 \\
\hline 10 & $\begin{array}{l}\text { Peserta didik } \\
\text { terfokus pada } \\
\text { materi } \\
\text { pembelajaran }\end{array}$ & 73 & 69 & 71 \\
\hline 11 & $\begin{array}{l}\text { Peserta didik } \\
\text { menanggapi } \\
\text { perintah guru } \\
\text { untuk bertanya } \\
\text { hal-hal yang } \\
\text { belum } \\
\text { dipahami }\end{array}$ & 86 & 78 & 82 \\
\hline 12 & $\begin{array}{l}\text { Peserta didik } \\
\text { menyimpulkan } \\
\text { materi } \\
\text { pembelajaran }\end{array}$ & 65 & 86 & 75,5 \\
\hline 13 & $\begin{array}{l}\text { Peserta didik } \\
\text { membacakan } \\
\text { hasil diskusi } \\
\text { bersama } \\
\text { kelompoknya } \\
\text { salam }\end{array}$ & 69 & 91 & 80 \\
\hline & 100 & 100 \\
\hline
\end{tabular}

Selain data aktivitas belajar peserta didik, peneliti juga melakukan tes untuk mengetahui hasil belajar peserta didik selama proses pembelajaran. Tes tersebut menunjukkan tidak ada lagi peserta didik yang memiliki nilai hasil belajar dengan kategori rendah dan sedang. Hal tersebut dapat dilihat pada gambar 2 berikut.

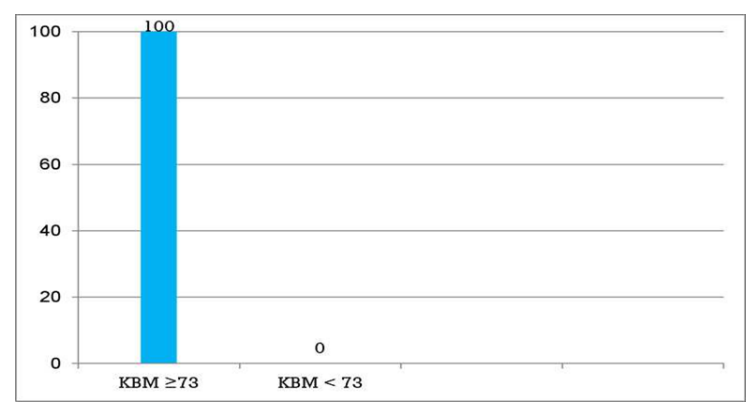

\section{Gambar 2. Batang Prest Tes pada Siklus II (Kedua)}

Berdasarkan tabel 3 pengamatan aktivitas belajar siklus II (kedua) menunjukkan bahwa rata-rata skor perolehan aktivitas belajar peserta didik adalah 83,03 atau dengan kategori "baik sekali” yaitu antara (80\% - 100\%), sehingga model pembelajaran kooperatif tipe think pair share (TPS) pada siklus II (kedua) peserta didik telah melakukan aktivitas belajar yang "baik sekali" pada mata pelajaran pendidikan agama Islam terutamanya pemahaman shalat sunnah.

menunjukkan bahwa tidak ada lagi peserta didik yang memiliki nilai hasil belajar dengan kategori rendah, melainkan seluruh peserta didik memiliki nilai dengan kategori yang tinggi. Ini bermakna bahwa pada siklus ke 2, sudah memenuhi peningkatan hasil belajar.

Pelaksanaan pembelajaran pada siklus II (kedua) ini bertujuan untuk meningkatkan hasil belajar peserta didik yang masih belum sepenuhnya dapat 
tercapai dengan sempurna pada siklus I (pertama). Akan tetapi, pada siklus II (ketiga) ini dapat terlihat bahwa peningkatan hasil belajar dengan jelas karena perubahan peserta didik dari siklus pertama hingga siklus kedua sangat meningkat dan telihat jelas.

Hasil refleksi dapat disimpulkan bahwa pada siklus II (kedua) ini penggunaan pembelajaran dengan menggunakan model pembelajaran kooperatif tipe Think Pair Share (TPS) telah mampu meningkatkan hasil belajar peserta didik dan pemahaman tentang shalat sunnah ini dapat dilihat dari indikator yang telah disebutkan.

Berdasarkan hasil analisis dan refleksi yang dilakukan pada siklus kedua ini, maka peneliti merasa tidak perlu lagi untuk melaksanakan tindakan pada siklus selanjutnya karena tujuan daripada penggunaan model pembelajaran kooperatif tipe Thnik Pair Share (TPS) untuk meningkatkan hasil belajar peserta didik dan pemhaaman tentang shalat sunnah pada mata pelajaran pendidikan agama Islam telah dapat mencapai tujuan yang diinginkan dan peserta didik telah mampu menunjukkan hasilnya dalam mata pelajaran pendidikan agama Islam dengan indikator nilai yang terus meningkat dari pertemuan yang pertama hingga pertemuan yang terakhir.

Berdasarkan hasil pengamatan awal yang dilakukan peneliti mulai dari sebelum dilakukan tindakan sampai pada tindakan siklus I (pertama) dan siklus II (kedua). Sebelum dilakukan tindakan peneliti menemukan bahwa model pembelajaran yang diterapkan oleh guru mata pelajaran pendidikan agama islam dalam proses pembelajaran yaitu model pembelajaran ceramah, penugasan dan Tanya jawab. Pada saat proses pembelajaran berlangsung sebagian peserta didik ada yang tidak memperhatikan dan peserta didik yang sulit memahami materi pembelajaran.

Adapun hasil penelitian selama proses pembelajaran mulai dari siklus I (pertama) dan siklus II (kedua) menunjukkan adanya perubahan yang signifikan dari hasil belajar peserta didik. Peserta didik lebih aktif dan bersemangat dalam mengikuti pembelajaran pendidikan agama Islam, sehingga rata-rata nilai hasil belajar peserta didik terus meningkat dan pemahaman siswa tentang shalat sunnah pun lumayan meningkat. 
Vol. 13, No. 1 (June 2021)

Hal tersebut juga didukung dengan meningkatnya antusias dan aktivitas peserta didik dalam partisipasinya mengikuti pembelajaran. Motivasi peserta didik dalam bertanya dan menjawab pertanyaan juga meningkat, sehingga menumbuhkan sikap yang kritis, saling menghargai pendapat orang lain dan inovatif dalam mengatasi persoalan yang dihadapi dalam pembelajaran. Adapun hasil aktivitas belajar peserta didik dari siklus I, dan siklus II yaitu: pada siklus I (pertama) hasil dari pengamatan aktivitas belajar peserta didik adalah kebanyak masih kurang antusias dalam pemahaman shalat sunnah dan siswa juga baru kali ini melakukan model pembelajaran kooperatif tipe think pair share (TPS), kemudian siklus II (kedua) siswa sudah ada peningkatan pemahaman tentang shalat sunnah jadi perolehan aktivitas belajar peserta didik berada pada kategori "sangat baik". Begitupun dengan hasil belajar peserta didik pada mata pelajaran pendidikan agama Islam yang mengalami peningkatan.

Pada siklus I (pertama) ditemukan beberapa masalah yaitu pada saat pembagian kelompok terjadi kegaduhan sehingga suasana kelas menjadi ramai karena merasa kurang cocok dengan anggota kelompok yang baru dibentuk tersebut.Dari tindakan awal ini nampak peserta didik masih kurang bisa bekerjasama dengan anggota kelompoknya, peserta didik juga masih kelihatan bingung dengan model yang diterapkan oleh peneliti. Peserta didik juga masih malu dalam bertanya, sehingga peserta didik banyak yang memilih diam dan beberapa peserta didik bercerita sesama teman sebangkunya.

Kemudian pada siklus II (kedua) ini menunjukkan kemajuan dan cukup memuaskan dalam partisipasinya dan antusias dalam mengikuti pembelajaran berlangsung. Peserta didik lebih bersemangat dan sudah mudah dikondisikan, peserta didik lebih tertib dan tenang di bandingkandengan siklus I. Saat diskusi berlangsung, peserta didik berinteraksi baik dengan kelompoknya, sebagian peserta didik aktif serta antusias saat pembelajaran berlangsung dan sebagian peserta didik memiliki peningkatan pemahaman tentang melaksanakan shalat sunnah. Oleh karena itu penelitian dicukupkan pada siklus II (kedua).Peningkatan tersebut terjadi karena selain penerapan model pembelajaran kooperatif tipe think pair 
INTIQAD: JURNAL AGAMA DAN PENDIDIKAN ISLAM

ISSN 1979-9950 (print) || ISSN 2598-0033 (online), http://jurnal.umsu.ac.id/index.php/intiqad

DOI: intiqad.v\%vi\%i.6763

Vol. 13, No. 1 (June 2021)

share (TPS), juga karena adanya hubungan kerjasama yang baik antara peneliti dengan peserta didik, peserta didik dengan peneliti dan peserta didik dengan peserta didik lainnya.

Masih ada beberapa peserta didik yang kurang aktif dan beberapa kelompok masih kurang bisa bekerjasama dengan kelompoknya. Setelah itu pada siklus II (kedua) cukup memuaskan dibandingkan dengan siklus I.

Data kumulatif dan presentase aktivitas belajar peserta didik secara keseluruhan pada mata pelajaran pendidikan Agama Islam mulai dari pra siklus, siklus I (pertama) dan siklus II (kedua) dapat dilihat sebagai berikut:

Tabel 4. Hasil Pemahaman Siswa Pada Siklus I dan II

\begin{tabular}{|c|c|c|c|}
\hline Siklus & $\begin{array}{c}\text { Rata- } \\
\text { Rata }\end{array}$ & SD & Keterangan \\
\hline I & 71,81 & 7,46 & $\begin{array}{c}\text { Belum } \\
\text { Tuntas }(< \\
73)\end{array}$ \\
\hline II & 80,91 & 7,43 & Tuntas \\
\hline
\end{tabular}

Berdasarkan data kumulatif Hasil Prest Tes pada siklus I dan Siklus II secara keseluruhan dapat dilihat bahwa pada siklus I (pertama) masih rendah sedangkan Pada Siklus II (kedua) mengalami peningkatan yang rata-rata siswa memiliki nilai yang tinggi.

\begin{tabular}{|c|c|c|c|c|}
\hline No & $\begin{array}{c}\text { Aktifitas } \\
\text { Belajar } \\
\text { Peserta Didik } \\
\end{array}$ & $\begin{array}{c}\text { Pra } \\
\text { Siklus }\end{array}$ & Siklus I & $\begin{array}{c}\text { Siklus } \\
\text { II }\end{array}$ \\
\hline 1 & $\begin{array}{l}\text { Peserta didik } \\
\text { masuk kelas } \\
\text { tepat waktu }\end{array}$ & 49,5 & 100 & 100 \\
\hline 2 & $\begin{array}{l}\text { Peserta didik } \\
\text { menjawab } \\
\text { salam dan } \\
\text { bersiap untuk } \\
\text { menerima } \\
\text { pelajaran } \\
\text { dengan berdoa } \\
\text { menurut agama } \\
\text { masing-masing }\end{array}$ & 58 & 100 & 100 \\
\hline 3 & $\begin{array}{l}\text { Peserta didik } \\
\text { yang hadir } \\
\text { mengucapkan } \\
\text { hadir dengan } \\
\text { santun ketika } \\
\text { namanya } \\
\text { disebut }\end{array}$ & 62,5 & 100 & 100 \\
\hline 4 & $\begin{array}{l}\text { Peserta didik } \\
\text { antusias untuk } \\
\text { mengikuti } \\
\text { pelajaran }\end{array}$ & 60,5 & 62,17 & 78 \\
\hline 5 & $\begin{array}{l}\text { Peserta didik } \\
\text { menjawab } \\
\text { pertanyaan dari } \\
\text { guru }\end{array}$ & 68,5 & 63,04 & 73,5 \\
\hline 6 & $\begin{array}{l}\text { Peserta didik } \\
\text { memperhatikan } \\
\text { penjelasan guru }\end{array}$ & 75,5 & 68,67 & 73,5 \\
\hline 7 & $\begin{array}{l}\text { Peserta didik } \\
\text { aktif dalam } \\
\text { pembelajaran }\end{array}$ & 58,5 & 66,28 & 78 \\
\hline 8 & $\begin{array}{l}\text { Peserta didik } \\
\text { mencatat } \\
\text { penjelasan dari } \\
\text { guru }\end{array}$ & 49,5 & 60 & 69 \\
\hline 9 & $\begin{array}{l}\text { Peserta didik } \\
\text { mendengarkan } \\
\text { arahan dari } \\
\text { guru }\end{array}$ & 60 & 59,76 & 82 \\
\hline 10 & $\begin{array}{l}\text { Peserta didik } \\
\text { terfokus pada } \\
\text { materi } \\
\text { pembelajaran }\end{array}$ & 51,5 & 62.15 & 71 \\
\hline 11 & $\begin{array}{l}\text { Peserta didik } \\
\text { menanggapi } \\
\text { perintah guru } \\
\text { untuk bertanya } \\
\text { hal-hal yang } \\
\text { belum dipahami }\end{array}$ & 58 & 57,58 & 82 \\
\hline 12 & $\begin{array}{l}\text { Peserta didik } \\
\text { menyimpulkan } \\
\text { materi } \\
\text { pembelajaran }\end{array}$ & 56 & 73 & 75,5 \\
\hline
\end{tabular}


ISSN 1979-9950 (print) || ISSN 2598-0033 (online), http://jurnal.umsu.ac.id/index.php/intiqad

DOI: intiqad.v\%vi\%i.6763

Vol. 13, No. 1 (June 2021)

\begin{tabular}{|c|l|c|c|c|}
\hline 13 & $\begin{array}{l}\text { Peserta didik } \\
\text { membacakan } \\
\text { hasil diskusi } \\
\text { bersama } \\
\text { kelompoknya }\end{array}$ & 49,5 & 55,26 & 80 \\
\hline 14 & $\begin{array}{l}\text { Peserta didik } \\
\text { mengucapkan } \\
\text { salam }\end{array}$ & 56 & 100 & 100 \\
\hline \multicolumn{2}{|l|}{ Jumlah } & $\mathbf{8 1 3 , 5}$ & $\mathbf{1 . 0 2 7 , 9 1}$ & $\mathbf{1 . 1 6 2 , 5}$ \\
\hline
\end{tabular}

rata-rata pada siklus II yaitu $80,92 \%$. Hal tersebut juga didukung dengan meningkatnya antusias dan aktivitas peserta didik dan partisipasinya mengikuti pembelajaran. Adapun nilai aktivitas belajar peserta didik yaitu

Berdasarkan data kumulatif pada pra siklus nilai rata-ratanya yaitu aktivitas belajar peserta didik secara keseluruhan dapat dilihat bahwa pada tahap pra siklus, aktivitas belajar peserta didik pada mata pelajaran pendidikan agama Islam sebesar 58,10\%. Pada siklus I (pertama), aktvitas belajar peserta didik pada mata pelajaran pendidikan agama Islam sedikit meningkat sebesar $73,42 \%$. Pada siklus terakhir atau siklus II (kedua), aktivitas belajar peserta didik pada mata pelajaran pendidikan agama Islam juga mengalami peningkatan sebesar $83,03 \%$.

\section{Simpulan}

Berdasarkan pembahasan sebelumnya, maka dapat disimpulkan hasil belajar peserta didik pada pembelajaran Pendidikan Agama Islam terutamanya tentang shalat sunnah di kelas VIII.3 SMP Negeri 2 Mattirobulu telah mengalami peningkatan. Nilai rata-rata hasil tes pemahaman siswa pada siklus I yaitu $71,80 \%$, dan nilai

$58,10 \%$, siklus I nilai rata- ratanya yaitu $73,42 \%$, dan nilai rata-rata siklus II yaitu $83,03 \%$. Motivasi peserta didik dalam bertanya dan menjawab pertanyaan juga meningkat, sehingga menumbuhkan sikap yang kritis, saling menghargai pendapat orang lain dan inovatif dalam mengatasi persoalan yang dihadapi dalam pembelajaran.

Model pembelajaran Kooperatif

Tipe Think Pair Share (TPS) ini memiliki peningkatan pemahaaman siswa tentang shalat Sunnah di SMP Negeri 2 Mattirobulu Kabupaten Pinrang.

Penelitian ini menunjukkan bahwa model pemeblajaran kooperatif tipe TPS dapat meningkatkan hasil belajar peserta didik (Amaliyah et al., 2019; Hetika et al., 2018; Oktaviani et al., 2020; Rismaningtyas et al., 2019; Suprapto, 2019). Maka, guru dapat mempertimbangkan model ini dalam proses pembelajaran di kelas. 
Vol. 13, No. 1 (June 2021)

\section{E. Daftar Pustaka}

Amaliyah, N., Fatimah, W., \& Abustang, P. B. (2019). Kontribusi Model Pembelajaran Kooperatif Tipe Think Pair Share (Tps) Terhadap Hasil Belajar Ips. Satya Widya, $35(2)$, 126-139. https://doi.org/10.24246/j.sw.2019. v35.i2.p126-139

Arikunto, S. (2017). Penelitian Tindakan Kelas. PT Bumi Aksara.

Hanapiah, N \& Suhana, C. (2009). Konsep Strategi Pembelajaran. Bandung, Refika Aditama.

Hetika, H., Farida, I., \& Sari, Y. P. (2018). Think Pair Share (TPS) as Method to Improve Student's Learning Motivation and Learning Achievement.

Dinamika Pendidikan, 12(2), 125-135. https://doi.org/10.15294/dp.v12i2.1 3561.

Isjoni. (2009.) Cooperative Learning. Bandung: Alfabeta.

Listyarini, L., \& Nafarin, S. F. A. (2020). Analisis Deiksis Dalam Percakapan Pada Channel Youtube Podcast Deddy Corbuzier Bersama Menteri Kesehatan Tayangan Maret 2020. Jurnal Pendidikan Bahasa Dan Sastra Indonesia, 9(1), 58-65. https://doi.org/10.15294/jpbsi.v9i1. 38628.
Majid, Abdul. (2013). Strategi Pembelajaran. Bandung: PT Remaja Rosda Karya

Moningka, M. J., \& Sahetapy, M. (2019). Penerapan Metode Think Pair Share Untuk Meningkatkan Kerja Sama Siswa Kelas Vii Pada Mata Implementation Think Pair Share Method To Increase Grade Vii Students ' Cooperation in Learning Integrated. 8, 72-76.

Oktaviani, Y., Ismaya, E. A., \& Widianto, E. (2020). The Implementation of Think Pair Share Assisted with Pop Up Media Increases Students' Outcomes. Jurnal Ilmiah Sekolah Dasar, 4(3), 430.

https://doi.org/10.23887/jisd.v4i3.2 7145

Pangestuti, A. A. (2017). Penerapan Model Pembelajaran Think Pair Share ( Tps ) Berbasis Lesson Study Untuk Meningkatkan Keterampilan Sosial Dan Hasil Belajar Kognitif Mahasiswa. Jurnal Penelitian Pendidikan Biologi, 1(2), 135-142.

Putri, N. P. I. A., Pujani, N. M., \& Devi, N. L. P. L. (2019). Pengaruh Model Pembelajaran Kooperatif Tipe Think Pair Share Terhadap Keterampilan Sosial Dan Prestasi Belajar Siswa Smp. Jurnal Pendidikan Dan Pembelajaran Sains Indonesia (JPPSI), 2(2), 92. 
ISSN 1979-9950 (print) || ISSN 2598-0033 (online), http://jurnal.umsu.ac.id/index.php/intiqad

DOI: intiqad.v\%vi\%i.6763

Vol. 13, No. 1 (June 2021)

https://doi.org/10.23887/jppsi.v2i2.

19377

Rismaningtyas, R. ., Sujatmiko, P., \& Kurniawati, I. (2019). Eksperimentasi Model Pembelajaran Kooperatif Tipe Think Pair Share (TPS) pada Materi Pokok Trigonometri Ditinjau dari Minat Belajar Matematika Siswa Kelas X Semester Ii Sma Negeri 6 Surakarta Tahun Pelajaran 2018/2019. Jurnal Pendidikan Matematika Dan Matematika (JPMM) Solusi, III(4), 367-382.

Riyanto, Y. (2009). Paradigma Baru Pembelajaran. Jakarta: Kencana Prenada Media Group

Rusman. (2011). Model-model Pembelajaran, edisi ke dua. Jakarta, PT Raja Grafindo Persada.

Sardiman, A.M. (2012). Interaksi \& Motivasi Belajar Mengajar. Jakarta: PT Raja Grafindo Persada.

Sadipun, B. (2020). Penerapan Model Pembelajaran Kooperatif Tipe Think Pair Share Untuk Meningkatkan Prestasi Belajar Ips Siswa Kelas V Sdi Ende 14. Inteligensi : Jurnal Ilmu Pendidikan, 3(1), 11-16. https://doi.org/10.33366/ilg.v3i1.14 61.

Siregar, E \& Nara, H. (2011). Teori Belajar dan Pembelajaran. Bogor: Ghalia Indonesia.

Suprapto, N. S. (2019). ISSN 2615-3939 IAIN Kudus http://journal.stainkudus.ac.id/index .php/jmtk. Jurnal Pendidikan Matematika, 2(2).

Tembang, Y. (2018). Penerapan Model Pembelajaran Think Pair Share untuk Meningkatkan Aktivitas Belajar IPA Siswa Kelas IV SD. Jurnal Ilmiah Sekolah Dasar, 2(1), 46.

https://doi.org/10.23887/jisd.v2i1.1 3928

Yuliati, E. (2020). Penerapan Pembelajaran Kooperatif Tipe TPS (Think Pair Share) untuk Meningkatkan Hasil Belajar PKn di MI Negeri 1 Yogyakarta. Jurnal Pendidikan Madrasah, 4(2), 149156.

https://doi.org/10.14421/jpm.2019.4 2-03 